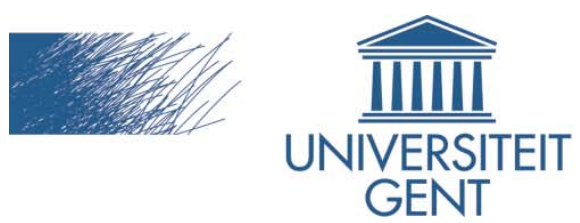

biblio.ugent.be

The UGent Institutional Repository is the electronic archiving and dissemination platform for all UGent research publications. Ghent University has implemented a mandate stipulating that all academic publications of UGent researchers should be deposited and archived in this repository. Except for items where current copyright restrictions apply, these papers are available in Open Access.

This item is the archived peer-reviewed author-version of:

Differences in retail strategies on the emerging organic market

Aertsens, J., Mondelaers, K. and Van Huylenbroeck, G.

In: British Food Journal, 111 (2), 138-154, 2009.

To refer to or to cite this work, please use the citation to the published version:

Aertsens, J., Mondelaers, K. and Van Huylenbroeck, G.. (2009). Differences in retail strategies on the emerging organic market. British Food Journal 111 (2), 138-154. 10.1108/00070700910931968 


\title{
Differences in retail strategies on the emerging organic market
}

\author{
Published as...
}

Aertsens, J., Mondelaers, K. and Van Huylenbroeck, G. (2009), "Differences in retail strategies on the emerging organic market", British Food Journal, Vol. 111 No. 2, pp. 138-154.

http://www.emeraldinsight.com/10.1108/00070700910931968

Correspondance: Joris.Aertsens@ugent.be

Keywords: Retailer, marketing strategy, organic, retailing mix, emerging markets

Category: Research paper / case study

\begin{abstract}
Introduction: The organic product market can be considered as an emerging market. Since the 1990s it has experienced rapid growth and supermarket chains have become the sales channel with the largest market share and are the main driver for further growth. However, different supermarket retail groups have very different strategies concerning the marketing of organic products. Some take a leading position and invest many resources in developing the market, while others apply an adaptive strategy to minimise their costs whilst providing a limited range of organic products or even do not invest in the organic segment.
\end{abstract}

Purpose: To gain insight into the different strategies of retailers which are active in the organic product market and to explain the drivers which may underlie them.

Findings: The different strategies used by retailers to market organic foods are associated with the overall characteristics and marketing strategies of the retail groups. Some retail groups have clear 'first mover' advantages from engaging in the organic product line, while for others an adaptive strategy is more appropriate.

Methodology/Approach: Our findings are based on an analysis of the strategies of the three most important Belgian retailers that market organic products and in particular organic beef. Data were collected through interviews with the retailer's staff and through observations in retail outlets. Also GfK-household panel data which recorded all purchases of 3000 Belgian households and an own postal survey with 529 respondents were used as data sources.

Research and Practical implications: The insights from this paper will help the understanding and facilitate the development of future strategies for organic and other high value or premium products which will be of interest to researchers and stakeholders active in these markets. The retail sector is not a single homogeneous block, but instead consists of retailers which pursue quite different strategies. This concept may have major implications for the future development of high value markets.

Originality / value of the paper: Existing relevant theories were applied to the adoption of the organic product line, a segment in the portfolio of retailers that is becoming more important. The empirical material collected sheds new light on the drivers behind retail strategies. 


\section{Introduction}

As can be seen in figure 1, below, main growth in organic production occurred only in the 1990s, following a number of food scares in the conventional sector. In the last decade organic markets in the world and in Europe have grown strongly (Hamm and Gronefeld, 2004). Sahota (2007) reports a growth of the global organic food and drink market revenue of $43 \%$ between 2002 and 2005. The European organic market comprises over half of global revenues and its growth has been estimated at 10 to 15\% in 2005 (Richter and Padel, 2007). Different sources expect that in the next few years global growth rates will be 15\% (Agriholland, 2007) to 20\% (Organic Monitor, 2006). Thus, the organic market is the fastest growing sector of the food industry and exceptionally high market growth rates are leading to undersupply in various regions (Organic Monitor, 2007).

Figure 1: Evolution of organic land and farms in the European Union, 1985-2005

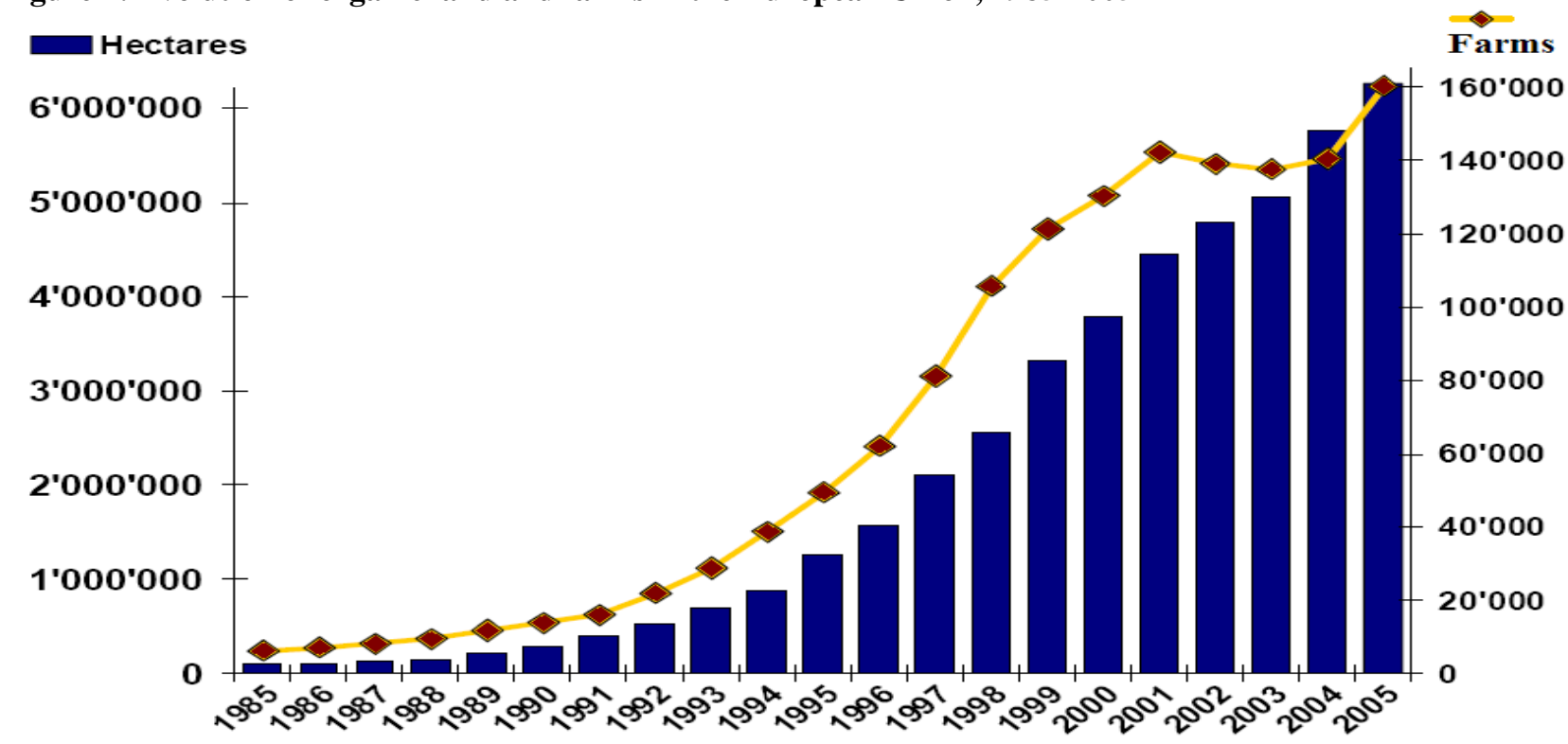

Source: Willer and Yussefi (2007)

As consumers become more sophisticated in their consumer behaviour towards organic foods, companies are focusing on supply chain management to ensure traceability, high quality, sufficient supply volumes and supply continuity. As assuring supply becomes a major concern, a number of European companies have started to invest in developing countries to lock-in supply (Organic Monitor, 2006).

While supermarket chains dominate the sales of organic vegetables and fruit in Europe with a market share of 48\% (Organic Monitor, 2005) experts rank them as the most important sales channel for future organic food market development both in urban and rural areas (Padel and Midmore, 2005). However, strong differences exist between European retailer groups with respect to marketing organic products (Richter and Hempfling, 2002).

In this paper we assess these differences more deeply, based on an in depth analysis of the strategies of the three largest Belgian retailers selling organic products. We explain why the strategies differ markedly even though the general characteristics of the retailers seem to be similar. Both the marketing mix and the organisation of the supply chain are considered. The general findings are relevant to other countries and non organic premium products. 


\section{Structure of the article}

In the next sections the methodology and the theoretical framework are explained. We formulate some hypothesis based on a review of the literature. This is followed by a description of the organic market structure in Belgium. Next, we focus on the overall characteristics and strategies of the three retailers studied. Then, the overall strategy is related to the strategy in marketing organic products in general and organic beef in particular. In the following discussion we come back to the hypotheses and use the empirical findings to discuss them. The paper ends with a general conclusion.

\section{Methodology}

Data for our analyses are combined from different projects studying the organisation and development of the organic sector in Belgium, between February 2003 and the end of 2007. Information concerning the strategies of the retailers was collected through interviews with at least five staff members at each of the retailers. The contacted staff members belonged to different departments (Purchase, Quality and Merchandising, Marketing) and were involved in different product categories (e.g. organic beef and organic vegetables). Also a point of sales director of the retailer group has been interviewed. These data were combined with our own observations at the points of sale and a review of press communications and relevant reports. GfK-household panel data, recording all purchases of 3000 Belgian households, were used to compare the importance of different sales channels. A postal survey with 529 respondents and a response rate of $44 \%$ were used to gain insight in the behaviour and perception of Belgian consumers towards organic products.

\section{Theoretical framework}

In this section we review the literature around this subject and examine a number of hypotheses. Richter and Hempfling (2002) who studied strategies of retailers for marketing organic products in eleven European countries found that these may differ importantly. They identified three main strategies. First, a "maximum strategy", which involves: (i) a large range of more than 400 different organic products at the points of sales, (ii) making organic products a significant part of the company's advertising and promotional campaigns, (iii) assuring the quality of the products. Second, a "basic strategy" involving a range of 50 to 250 organic products. Third, a "minimum strategy" involving a range of no more than 50, mostly dry, organic products. Richter and Hempfling (2002) also categorized retailers as "leaders" or "adapters". Leaders follow a maximum strategy and want to be the regional market leader in organic products. Adapters apply a basic or minimum strategy. Adapters compose their organic product inventory according current trends in demand or as a reaction to the strategies of their main competitors. They sell organic products, but without strong active engagement and effort.

When it comes to tools to put certain products in the market, Lazer (1961) argues that retailers can use their retailing mix in both the commercial and operational part. The commercial part aims at increasing effectiveness by adjusting the Product mix, the Price mix, the Presentation and the Promotion mix. The operational part mainly aims at increasing the efficiency through an adequate Place mix, Physical distribution mix and Personnel mix (Brown et al., 2005). Jointly these concepts are better known as the seven retail P's. Further in the paper we describe important differences between retailers in the positioning of organic products using their retailing mix. We also refer to Mickwitz (1959) who argues that in the different phases of the Product Life Cycle, a different implementation of the marketing mix is optimal. 
Wind (1982) describes different product portfolio models and gives some criteria to evaluate the assortment. The criteria mostly used are (a) the turnover and the phase in the Product Life Cycle, (b) the competitiveness of the firm for this product, (c) the generated profits, (d) the risk incurred and (e) the firm's resources allocated to the adoption of the product. These are interesting elements that we will use further.

Another interesting element in the discussion, is the idea of Chen et al. (2006) who suggest that there exist strategic product categories that are more important than others in consumers' store choice decisions. Marketing research also suggests that in-store stimuli such as display and atmosphere have a great influence on consumer buying behaviour and may encourage sales by maximizing impulse buying and cross-selling (Donovan and Rossiter, 1982, Kotler, 1974, Corstjens and Doyle, 1981). For example, a factorial experiment revealed that an in-store display of an item creates excitement and increases the average amount purchased (Chevalier, 1975). The effect of one category on the profits of other categories in the store is particularly important in the calculus of marketing decision making. Retailers have to pay extra attention for these strategic product categories (Chen et al., 1999).

The question is then what makes some products of strategic importance to retailers? As strategic products attract (new) customers to the retailer, in order to identify strategic products, adapting Abell (1980), retailers need to answer the following related questions: "who are our main customers?" and "what products and services do they want?". Retailers can answer to these in three steps: 1) Segmentation of the customers based on their preferences; 2) Targeting or choosing the most interesting customer segments; 3) Positioning: developing a marketing mix to reach these segments. For this positioning which can be seen as a form of differentiation, the retailer should develop a product offer, that will be regarded as most desirable by the customers in the targeted market segment (Sanchez and Heene, 2004). When different retailers target different customer segments, their optimal product mix should be different. We can than argue that products that especially attract targeted customers are of strategic importance to retailers. The attraction can come both from functional value as from underlining the image of the retailer in aspects that are important to the targeted customers.

It is interesting to combine the concept of "strategic" product lines with the framework of Morschett et al. (2006) which is based on Porter (1985). They argue that two distinctive types of competitive strategies exist: the cost leadership and the differentiation strategies. Strategic products may play a fundamental part in a retailer's differentiation strategy.

Could organic products have strategic importance and if so what makes them special for consumers? Several authors examined the factors that influence consumers to choose organic rather than conventional food (Midmore et al., 2005, Zanoli and Naspetti, 2002, Zanoli, 2004).

Both private use values such as health, taste and freshness, and public use values such as environmental conservation and animal welfare play an important role (Oughton and Ritson, 2007, Krystallis and Chryssohoidis, 2005, Yiridoe et al., 2005, Baltussen et al., 2006). Codron et al show that recently, ethical, health and environmental values become increasingly more important for consumers (2006). Wirthgen (2005) also indicates that marketing on "the regional origin" can be a successful strategy for product differentiation. Thus as consumers perceive that organic products score very well on these points, some retailers may develop organic, fair trade and sustainable products strongly to enforce their image as social responsible retailer. De Ferran and Grunert (2007), Hughes (2005) , Jones et al. (2005) show that these values are indeed taken up by some retailers, e.g. as part of their corporate social responsibility policy. 
“Organic" as an emerging market. When retailers develop a strategy for marketing organic products it is important to take into account that this is still an emerging, innovative market. Ansoff (1957) and Danneels (2002) argue that the introduction of new products in new markets usually requires special efforts and thus demands a lot from the retailers' resources. Danneels (2002) identifies two types of firm competences that may be required for product innovation: (1) new technological competences, and (2) new customer competences. For the emerging organic market both competences have to be developed. Danneels (2002) indicates this situation as "pure exploration". This means that the choice for a "maximum strategy" for promoting "organics" demands a lot of resources that not all retailers can or want to provide. For some it may be more interesting to adopt a "second mover strategy" in order to limit costs or resources (Lieberman and Montgomery, 1998).

These combined elements from the literature result in the following hypotheses, which we will return to after the presentation of the empirical findings.

Hypothesis 1: "In order to favour strategic products, retailers may not only use the commercial but also the operational factors of the retail mix".

Hypothesis 2: “Organic products may be a strategic product category for some retailers".

Hypothesis 3: "The (perceived) characteristics of organic products have strategic importance for retailers that want to create an image with the same values"

Hypothesis 4: Due to the characteristics of the organic market as an innovative, emerging market, there may be certain first mover advantages"

Hypothesis 5: "Investments by retailers in products which have strategic importance for them, will pay off relatively fast"

Hypothesis 6: "For some retailers organic products have no special strategic importance

Hypothesis 7: "For emerging product markets, some retailers may benefit more from a second mover strategy"

\section{Characteristics of the organic market in Belgium}

Both Richter (2002) and Hamm and Gronefeld (2004) consider the Belgian organic market as a growth market. However after the boosting effect of the major food crises in 1999 (dioxin) and 2001 (BSE), total consumer expenditures on organic food have dropped again by 28\% between 2001 and 2005 (Stockemer and Van Raemdonck, 2005). With a total sales turnover of 201 million euro for organic fresh products and a share of 1.5 percent of total fresh food expenditures in 2005 the market for organic fresh food remains marginal in Belgium (VLAM, 2006).

In the early 1990s, specialised shops were the dominant sales channel for organic products in Belgium. But, as indicated in Table 1, their share has decreased significantly and continuously, predominantly in favour of supermarkets. 
We can also conclude from Table 1 that alternative channels, such as markets and on farm sales capture a higher share of the organic product market compared to their conventional counterparts. The explanation is that organic has a connotation of "alternative" that matches well with the alternative channels both in the view of buyers and sellers.

Table 1: Market share, growth rate of share and ratio organic versus conventional share for different sales channels

\begin{tabular}{l|cc|c|c}
\hline & \multicolumn{2}{|c|}{ Market share (\%) } & Average growth & $\begin{array}{c}\text { Organic vs. conventional } \\
\text { share (\%) }^{\mathbf{3}}\end{array}$ \\
\hline 2001 & $\mathbf{2 0 0 5}$ & rate (\% points) $^{\mathbf{2}}$ & 90 \\
Supermarket & 49 & 60 & $+5,3$ & 90 \\
Specialized shop & 32 & 20 & $-10,5$ & 190 \\
\hline Other & 19 & 20 & $+2,9$ & ${ }^{4}$ \\
\hline
\end{tabular}

1. based upon expenditure per capita (VLAM, 2006); (Baecke et al., 2002)

2. average growth of market share yearly, 2001 base year

3. data for vegetable products (Mondelaers and Van Huylenbroeck, 2005)

Other: markets, on farm sales, box schemes and others

\section{Main characteristics and strategy of the retailers}

In order to respect confidentiality we refer to the three main Belgian retailers of organic food as R1, R2, and R3. We remark that the third retailer has also three supermarkets where only organic products are sold: we refer to these as R3-bio. Further there are also retailers in Belgium, e.g., some hard discounters, who so far do not sell (fresh) organic products.

Table 2 presents the main characteristics of the retailer groups investigated. The total number of super- and hypermarkets they operate in Belgium varies between 125 and 170. One noteworthy difference is that R2 has also an important number of hypermarkets $\left(>2500 \mathrm{~m}^{2}\right.$ or 27.000 square feet), whereas R1 and R3 only have supermarkets $\left(<2500 \mathrm{~m}^{2}\right)$. Another distinction for R2 is its more important section of non-food articles, contrary to R1 and R3, which only offer these products to a limited extent.

Table 2: General characteristics of the retailers, overview

\begin{tabular}{|l|l|l|l||l|}
\cline { 2 - 4 } \multicolumn{1}{c|}{} & \multicolumn{1}{c|}{$\mathbf{R 1}$} & \multicolumn{1}{c|}{$\mathbf{R 2}$} & \multicolumn{1}{c|}{ R3 } & R3-bio \\
\hline hyper (F1) and/or super (F2) & F2 & F1+ F2 & F2 & F2 \\
\hline specialisation & Food & Food+ Non Food & Food \\
\hline \# points of sales (F1+ F2) 2004, in B & 125 & F1: $56 \quad+F 2: 78$ & 170 \\
\hline average surface of P0S (m²) & 1400 & F1: 4000; F2: 1700 & 1400 \\
\hline turnover 2003 (billion EUR) & 3,7 & 4,6 & 3,6 & Food \\
\hline \% of total sales volume for F1+ F2 & $20 \%$ & $31 \%$ & $19 \%$ & 670 \\
\hline
\end{tabular}

PoS: Point of Sales

sources: interviews, press, yearly firm reports. $\left(^{*}\right) \mathrm{F} 1:>2500$ m²; F2: 650-2500m²;

In Table 3, below, we summarise some characteristics from the retailing mix that indicate how the different groups position themselves in the market. 
The main strategy of $\mathbf{R 1}$ is a market specialisation strategy or in this case a differentiation strategy (Sans, 2003). As indicated in R1's mission statement, their key focus is delivering superior value and gaining a leading position in mature and emerging food segments. R1 particularly targets consumers searching for high quality, convenience and healthy products. This is implemented by developing strong local chains and maintaining high social, environmental and ethical standards. R1 also provides a large selection of high quality food products in a very pleasant shopping environment. Special attention is given to several "emerging” product segments, such as organic products, fair trade and convenience food (Belga Press Release, $4^{\text {th }}$ of January 2007). To maintain their quality image and to strengthen consumer loyalty, R1 attaches an extra label for quality control and traceability to these emerging product lines. R1 tries to be the market leader in these "niches" by being the first in offering the products. The prices of R1's products are however on average 19\% higher than the ones offered by R3. The price difference amounts to 55 percent when basic unbranded products are compared (Labarre and Starquit, 2005).

The overall strategy of $\mathbf{R 2}$ is different. R2 aims for full market coverage by offering food and non-food, branded and unbranded products in both high and low price categories. Instead of targeting specific consumer segments, R2 tries to attract the total population of consumers. R2 hereby challenges both R1 and R3. At the points of sale they opt for a pleasant shopping environment. The number of retail staff available for assisting clients is however smaller when compared to R1 (especially when expressed per $\mathrm{m}^{2}$ of sales area). Although R2 claims to offer the lowest price for some products, on average their prices are intermediate between R1 and R3: +9\% with respect to R3 (Labarre and Starquit, 2005).

In its turn the overall strategy of R3 is different. R3 focuses especially on an efficient "operational mix" or in other words on a low cost logistic. This strategy is visible at the points of sale that resemble a warehouse. The points of sale are not nicely decorated, but aim at a practical handling when supplying the racks and during shopping. R3 specifically targets consumers that want to buy food at the best quality/price ratio. R3's unique selling proposition is based upon the lowest price in the region both for national brands, which account for $70 \%$ of their product range, and "store brand" products.

Table 3: Strategy of the retailers, overview

\begin{tabular}{|c|c|c|c|c|}
\hline MARKETING MX & $\mathbf{R} \mathbf{1}$ & $\mathbf{R} 2$ & R3 & R3-bio \\
\hline food prices (strategy) & High & medium-low & lowest & low or medium \\
\hline assortment of food & very large & large & large & large \\
\hline assortment of non-food & Medium & F1:very large; F2: large & medium & small \\
\hline quality & +++ & ++ & +++ & +++ \\
\hline shopping atmosphere & very pleasant & (very) pleasant & basic / ok & pleasant \\
\hline service, \# servants in shop & ++ & + & ++ & ++ \\
\hline
\end{tabular}

source: press releases + own observations

In Table 4 the price premiums for national brands, unbranded basic ('white') products and organic products of R1 and R2 are compared to R3's. The data clearly show that R3 has the lowest price for all products.

Table 4: Price premium of R1 and R2 compared to R3 


\begin{tabular}{l|c|c|c}
\hline & National brands $^{\mathbf{1}}$ & Basic products $^{2}$ & Organic products $^{3}$ \\
\hline R1 & $+10 \%$ & $+55 \%$ & $+19 \%$ \\
R2 & $+6 \%$ & $+3 \%$ & $+29 \%$ \\
\hline
\end{tabular}

1. source: (Labarre and Starquit, 2005): 683 stores visited, 141 national brand products in the basket

2. source: (Labarre and Starquit, 2005): 683 stores visited, 73 basic products ('white products')

3. source: (Jooken and Niclaes, 2002): 86 stores visited, 41 products in the basket

\section{Retailers and their marketing strategy for organic products}

In this section we compare the marketing strategies of the three retailer groups. The main characteristics are summarised in Table 5 below.

R1 makes a real effort in selling organic products, using the different elements of the marketing mix. In Belgium, R1 was the first to offer organic products, starting in 1985 with organic bread and some other basic products. Concerning the organic product mix, R1 excels at product range level, with 650 product references in the organic version or $4 \%$ of their total product range compared to 236 for R2 and 312 for R3. R1's product range covers all the main food product classes. Table 4 indicates that R1 comparatively takes a lower profit margin on organic products. Where for the basic products R1's price is on average 55\% higher than R3's, for organic products the price is only 19\% higher than R3's. And where R1 has higher prices than R2 for the conventional national brands and basic products its prices are about $10 \%$ lower for the organic products. With respect to the presentation, R1 places its organic products in positions which are highly visible, attracting attention towards them by systematically using green signalling flags marked with "bio". Promotion is also emphasized by advertising the offer of organic products in their weekly 'flash'-magazine and the organization of an 'organic products' week. Due to this combined approach R1 has increased its share of the total sales of organic products in super- and hypermarkets in Belgium to 50\%, though its share of overall super- and hypermarket sales is only $20 \%$. R1 has attained this relatively high market share, even while the average price of its organic products is 19 percent higher than R3's.

R2's strategy is very different when it comes to selling organic products. R2 makes no special efforts to promote them. R2's organic product range consists of only 236 products, which is about $2.6 \%$ of their total product range. Organic products constitute less than one percent of their total turnover and organic sales have declined during the last two years. Whilst prices for basic products at R2 are on average 3\% higher than at R3, prices for organic products are 29\% higher than at R3. And where prices for the basic products are about one third lower than at R1 the prices of organic products are about $10 \%$ higher. With respect to the presentation, organic products are not placed at more visible spots in their stores. Flags are not used systematically to indicate the placement of organic products. Sometimes the organic products are placed badly on the shelves such that the organic label is not visible. These observations indicate the lack of knowledge and/or attention of the employees at the point of sales concerning organic products. When it comes to the sales of organic vegetables, where R1 and R3 always provide vegetables of high quality, (Class 1), R2 provides lower quality (Class 2).

R3's strategy for organic products is part of the sustainable "Green Line” product policy. This policy emphasizes their willingness to promote environmentally friendly production and distribution. Starting from R3's basic concept that no superfluous costs may be made, the policy is translated as "investments in environmental friendliness take place if they pay back". R3 is creative in developing this concept by limiting transport miles, recycling, cost efficient and ecological packaging, use of wind energy, and other similar measures. Of the 312 organic products in R3's assortment, more than 190 are private label products. Organic food generates $2 \%$ of their turnover and the growth rate is $5 \%$ higher than for other products. The organic 
products are presented in highly visible places in store. As other "Green Line" products they are easily recognisable by a green price sticker on the shelves, while most products have white stickers and red stickers are used to indicate the cheapest products. An effort is made to promote "organic". R3 has a history of offering both basic and high quality products. In the last ten years many of its high quality products have been replaced by organic quality products.

Table 5: Strategy of the retailers, when supplying organic products in general

\begin{tabular}{|c|c|c|c|c|}
\hline & $\mathbf{R} \mathbf{1}$ & $\mathbf{R} 2$ & R3 & R3-bio \\
\hline assortment, or \# org. products in 2001 & 600 & 236 & 312 & 7000 \\
\hline org. fresh meat, cheese & available & available & not available & available \\
\hline org. vegetables, fruit, & available & available & available & available \\
\hline org. dairy, bread, juice, dried products & available & available & available & available \\
\hline retailers own org. mark and label & yes & yes & yes & yes \\
\hline turn over organic (mio EUR) & $\sim 80$ & $\sim 30$ & $\sim 55$ & $\sim 10$ \\
\hline $\begin{array}{l}\text { share of total organic sales by } \\
\text { supermarkets (\%) }\end{array}$ & $\sim 50 \%$ & $\sim 20 \%$ & $\sim 30 \%$ & \\
\hline organics as part of total turn-over & $\sim 2,2 \%$ & $\sim 0,7 \%$ & $\sim 1,5 \%$ & $100 \%$ \\
\hline placement of org. products & good not best & moderate & good & only organic \\
\hline flags / signaling & very visible flags & less visible & visible stickers & only organic \\
\hline prices of organic products & $119 \quad(=>+19 \%)$ & $129(=>+29 \%)$ & 100 (=reference) & $112(=>+12 \%)$ \\
\hline Quality of the org. Vegetables & high (cat.1) & medium (cat. 2) & high (cat.1) & high (cat.1) \\
\hline year of introduction of org. products & 1985 & 1996 & 1991 & 2001 = opening \\
\hline
\end{tabular}

Sources: collected information and own observations

R3 not only challenges the organic leadership role of R1 in its conventional stores, it also targets the organic heavy users in specialised shops: R3-bio. Up to the end of 2007 the number of specialised organic shops remains limited to three, but according to the chief manager of R3-bio the aim is to open up to 15 of these shops in the following years in order to have one in every city in Flanders. Given the rise in sales of organic products at these points of sale with $25 \%$ in 2004, the strategy seems successful (De Standaard, 2005). All food products in these shops are organic. The organic range of 7000 products is much deeper and wider compared to specialised shops or other supermarkets which enables customers to buy all the products on their shopping list in the organic version while choosing between a variety of alternatives. Some non-food products that give special attention to ecology are also for sale. These stores are still less profitable compared to the traditional points of sale of R3. But it is likely that when more of these shops open more profits will be made through economies of scale. The staff at R3-bio's points of sale is well informed about the meaning of organic products. A qualified herbalist is present in every R3-bio store.

\section{Retailers and their engagement in marketing organic beef}

In this section we compare the marketing of organic beef by the three retailer groups. This is summarised in Table 6 below.

R1 allocates relatively a large amount of resources to the marketing of organic beef and does this both in the commercial and operational part of its retail mix. One aspect of this is R1's 
active role in organising the supply chain. Already in 1997, before the dioxin and BSE food scares, R1 made an agreement with a cooperative of organic beef producers to provide high quality meat. By paying a very good price to the producers (see table 6) and cooperating for about 10 years, an important degree of trust has been created among these producers. This commitment helped to convince the producers to make important, sometimes "irreversible", investments in quality aspects that go beyond the requirements defined in the organic regulation. For example only animals from two specific breeds are allowed (Aertsens and Van Huylenbroeck, 2004). These measures explain why consumer prices of organic beef are 5\% higher than at R2. When taking account of all R1's efforts, the price charged to the consumers can be considered relatively low. R1 also promoted organic beef by emphasising its direct contact with the local producers' cooperative when advertising organic beef, thus appealing to consumers who attach more and more importance to food safety, traceability, origin and authenticity (Jones et al., 2001). By all these efforts, R1 succeeded in gaining a share of $72 \%$ in the turn-over of the organic beef sold by the super/hypermarkets in Belgium. This percentage is even higher than the $50 \%$ of the overall organic products mentioned before.

Table 6: Characteristics of retailers when supplying organic beef

\begin{tabular}{|c|c|c|c|}
\hline & $\mathbf{R} \mathbf{1}$ & $\mathbf{R 2}$ & R3 \\
\hline sales volume (kg per week), 2004 & 5800 & 1300 & 0 \\
\hline$\%$ of total sales in F1+ F2, 2004 & $72 \%$ & $16 \%$ & 0 \\
\hline start of supply of organic beef & 1997 & 1997 & \\
\hline role in chain organisation & important role & $\begin{array}{l}\text { outsourced to } \\
\text { transformator }\end{array}$ & \\
\hline effort in chain organisation & high & low & \\
\hline agreement on future producer price & fixed & market dependent & \\
\hline price paid to producers & very high $(120=+20 \%)$ & moderate (100) & \\
\hline consumer prices & $105=>(+5 \%)$ & 100 & \\
\hline risk in case of low demand & for producers & for producers & \\
\hline country of origin & Belgium & Belgium & \\
\hline
\end{tabular}

\begin{tabular}{|l|}
\hline R3-bio \\
\hline 245 \\
\hline $3 \%$ \\
\hline 2001 \\
\hline Moderate \\
\hline Moderate \\
\hline \\
\hline \\
\hline \\
\hline Belgium \\
\hline
\end{tabular}

source: own research

R2 invests little effort and less money in organising the supply of organic beef. In practice it has outsourced the organisation of the supply to a processor who also collects the animals from the organic farmers. The price paid to the producers of R2 is about $20 \%$ lower than R1's. Though the consumer price is 5\% lower than at R1's, the sold volume of organic beef is less than a quarter of R1's volume, due to a lack of promotional and other efforts.

As indicated above $\mathbf{R} 3$ does not supply fresh organic meat in its normal supermarkets. However it does so in its three exclusive organic supermarkets (R3-bio). This is due to several factors: First, R3 has a well organised high quality conventional butchery at all of its points of sale. These butcheries are an asset in attracting clients. According to the "organic reference standard" it is necessary to strictly separate between conventional and organic products. Therefore offering organic meat in this butchery is not allowed. Secondly, offering pre-packed organic meat is not considered a good option as the management argues that the conventional meat supplied is already of very high quality, and that it may have an antagonistic effect to offer a more expensive organic meat. Third, R3 argues that as it has three supermarkets selling only organic 
products (R3-bio) it does not make sense to offer all organic products also in the conventional supermarkets. They refer to this as avoiding "cannibalism”.

\section{Discussion}

In this section we match our empirical findings to the hypotheses that we formulated at the end of the theoretical framework. Our approach is more qualitative. Future research may test some of our hypotheses using a more quantitative approach.

Hypothesis 1: "In order to favour strategic products, retailers may not only use the commercial but also the operational factors of the retail mix".

The empirical data clearly revealed that R1 invested not only many resources from the commercial (Product quality and assortment, Price, Presentation, Promotion) but also from the operational mix in promoting the organic product segment. Especially its operational efforts in organising the organic beef chain highlighted this.

In contrast it became obvious that R2 did put very little effort in these different factors to promote organic products.

\section{Hypothesis 2: “Organic products may be a strategic product category for some retailers".}

For R1, the allocation of resources to the marketing of organic products strongly indicates the strategic importance of organic products for R1. Further R1 wants to differentiate itself from other retailers and to enforce its leading position as a quality distribution chain (Sans, 2003). In an interview, a representative of R1 confirmed this view: "The nice shopping environment and the large selection of high quality and differentiated products is attracting consumers who are willing to pay more for a better quality".

R1 specifically targets consumers that are not primarily price oriented. High income families form an important part of their loyal customers. Studies for Belgium (Stockemer and Van Raemdonck, 2005) and for Europe (Zanoli, 2004) point out that there is a positive relation between higher income and higher consumption of organic food. Furthermore, organic buyers, on average, have higher purchasing power, and they spend up to $4 \%$ more on Fast Moving Consumer Goods compared to an average Belgian household (Stockemer and Van Raemdonck, 2005). For R1 this makes that they are a segment that they want to attract to their points of sales.

\section{Hypothesis 3: "The (perceived) characteristics of organic products have strategic importance for retailers that want to create an image with the same values".}

Before, we learned that R1 particularly targets customers searching for high quality, healthiness, new and artisanal food products. These characteristics match very well with what consumers perceive to be properties from organic products.

It became clear that the perceived environmental friendliness of organic products fits very well in R3's sustainable “Greenline” strategy. This helps to explain why "organic products” are important for R3. 


\section{Hypothesis 4: Due to the characteristics of the organic market as an innovative, emerging market, there may be certain first mover advantages.}

Lieberman and Montgomery (1998) indicate that first mover advantages may find their origin in three factors: (i) gaining technology leadership, (ii) gaining control of resources and (iii) binding customers to the firm. Considering the commercialisation of organic (beef) products by R1 mainly the second and third factors are relevant. Through its strategy R1 is "gaining control of the resources". In the organic sector the number of supplier organisations is still very limited (especially in Belgium). As indicated in Table 6, R1 'controls' $72 \%$ of the total organic meat volume through their vertical alliances, leaving only limited options for the other retailers. This is similar for other organic segments, e.g vegetables. The approach of R1 in striving for sustainable exclusive relationships with high quality suppliers, makes them gain control over local resources that their competitors will not be able to copy. Several papers, e.g. Bernués et al. (2003), find that consumers of (organic) meat or organic products in general prefer the products to be produced in their home country. Through its strategy R1 is also "binding customers". Being the first and leading firm to sell organic products thus results in first mover advantages.

In this context it is interesting to apply Mickwitz' (1959) findings to R1's strategy of marketing organic beef. Mickwitz found that in succeeding phases of the Product Life Cycle, different marketing mix instruments become more efficient. Also, more investments are needed in the early phases (introduction, growth, maturity) and more gains will occur in the later phases (saturation, decline). Following Mickwitz, during the introductory phase of the Product Life Cycle, R1 has especially focussed on providing high quality organic beef by specifying process criteria to its suppliers. The high prices R1 pays to organic beef producers are not charged completely to the consumers. R1 in the past ten years applied a market penetration strategy (and certainly not a skimming strategy). In the second or growth phase, again following Mickwitz, the retailer started to invest more in promoting organic beef as the growth of organic beef consumption was stagnating. The investments of R1 in marketing organic beef have certainly paid off in terms of market share. Although R1's investments in developing the supply of organic beef are not covered by the consumer price of organic beef in the short run, following Mickwitz theory, they will most probably be covered in the long run.

\section{Hypothesis 5: "Investments by retailers in products which have strategic importance for them, will pay off relatively fast.”}

The chief organic beef buyer at R1 claimed: "We are rather making losses than profits, when commercialising organic beef. But it is an investment in the future”. Investments in the overall quality of the supply of organic (beef) products as a strategic product will underline the quality image of R1 positively. This may attract (new) customers that buy other products and help to recover these investments faster.

This hypothesis has the important consequence that retailers should pay (more) attention to effects of some product categories on others. Now, a lot of retailers have purchase and sales managers that are responsible for strictly delimited categories, this organisational structure may hamper the development and promotion of strategic products, like organic products.

\section{Hypothesis 6: “For some retailers organic products have no special strategic importance”}


From our empirical part it became clear that for R2 "organic products” have much less importance than for R1. Richter and Hempfling (2002) would describe R2's strategy as a "basic" or "adapting” strategy. For R2 organic products have no special significance. The provision of a limited range of organic products is mainly targeted as a defence against R1 which might be successful in attracting and holding new customers from R2.

We noticed a strong positive correlation with the consumer segments that are targeted. Where R1 targets especially high income consumers, R2 targets all segments. Further in the retailer spectrum there are hard discounters in Belgium that do not offer (fresh) organic products at all.

\section{Hypothesis 7: “For emerging product markets, some retailers may benefit more from a second mover strategy".}

R2's and R3's basic strategy make sense because of "second mover advantages". As adapters or second movers they can reduce their costs. R1, as the first-mover firm incurs higher costs partly by having to learn competences partly in educating its customers about organic (beef) products, but mainly by instructing producers to supply high quality organic beef. As the learning experience is to some extent spread among all producers in the organic beef sector, R2 and R3 on this point benefit from this learning experience and incur much lower costs. Also by applying a "wait and see" policy they do not run the risk of investing in a market that might prove unbeneficial.

\section{Conclusion}

We noticed that different retailer groups which at first sight have similar characteristics, can have very different strategies for marketing organic products. For some retailers, organic products are of strategic importance, as part of a differentiation strategy. This is due to their perceived values, such as environmental friendliness, social responsibility and high quality. The merit of strategic products in this sense are not in generating a lot of sales but in their possibility to improve the retailers image and thus attract extra customers who will also buy additional products at the store. Some retailers are willing to take very low margins and to invest many resources in all seven (commercial and operational) factors of the retailing mix in order to put these strategic products in the spot light. When the products, as is the case for organic products, are part of an emerging market, the development of both new technological and customer competences may be necessary. This demands huge investments and time but may result in first mover advantages by binding both suppliers and clients to the retailer. Other retailer groups for whom organic products are not of strategic importance, can benefit more from a second mover strategy. They offer only a basic assortment and thus limit the risk of investing a lot in an emerging market that might turn out to have a limited future. However when the emerging market would turn out to have a bright future, the "adapters" will invest later and then benefit from the learning experience that has already been developed in the sector.

Our results also hold for other product types in emerging markets that for some retailer groups have strategic importance such as fair trade products, regional high quality products, convenience products. It may be therefore important to do more research around these concepts,

\section{Acknowledgement}

The authors gratefully acknowledge the suggestions of Chris Firth (HDRA, Coventy, England) that helped to improve the quality of the paper. 


\section{References}

ABELL, D. (Ed.) (1980) Defining the Business: The starting Point of Strategic Planning, Englewood Cliffs, NJ: Prentice-Hall.

AERTSENS, J. \& VAN HUYLENBROECK, G. (2004) Role and value of a producers' cooperative in small vertical supply chains: the case of an organic beef chain in Belgium. EURESCO-conference: Vertical Markets and Cooperative Hierarchies: The role of Cooperatives in the International Agri-Food Industry Strategies and Organization of Agri-Food Cooperatives: Quality Assurance and Vertical Coordination. Chania, Greece.

AGRIHOLLAND (2007) Aandacht voor gezond en veilig voedsel stuwt vraag naar biologisch. Agriholland.

ANSOFF (1957) Strategies for diversification. Harvard Business Review, September-October.

BAECKE, E., ROGIERS, G., DE COCK, L. \& VAN HUYLENBROECK, G. (2002) The supply chain and conversion to organic farming in Belgium or the story of the egg and the chicken. British Food Journal, 204, 162-174.

BALTUSSEN, W. H. M., WERTHEIM-HECK, S. C. O., BUNTE, F. H. J., TACKEN, G. M. L., VAN GALEN, M. A., BAKKER, J. H. \& DE WINTER, M. A. (2006) Een Biologisch Prijsexperiment; Grenzen in zicht? IN LEI (Ed.).

BERNUÉS, A., OLAIZOLA, A. \& CORCORAN, K. (2003) Labelling information demanded by European consumers and relationships with purchasing motives, quality and safety of meat. Meat Science 65 (2003) 1095-1106, 65, 1095-1106.

BROWN, J. R., DANT, R. P., INGENE, C. A. \& KAUFMANN, P. J. (2005) Supply chain management and the evolution of the "Big Middle". Journal of Retailing, 81, 97-105.

CHEN, Y. L., CHEN, J. M. \& TUNG, C. W. (2006) A data mining approach for retail knowledge discovery with consideration of the effect of shelf-space adjacency on sales. Decision Support Systems, 42, 1503-1520.

CHEN, Y. X., HESS, J. D., WILCOX, R. T. \& ZHANG, Z. J. (1999) Accounting profits versus marketing profits: A relevant metric for category management. Marketing Science, 18, 208-229.

CHEVALIER, M. (1975) Increase in sales due to in-store display. Journal of Marketing Research, 12, 426-431.

CODRON, J. M., SIRIEX, L. \& REARDON, T. (2006) Social and environmental attributes of food products in an emerging mass market: Challenges of signaling and consumer perception, with European illustrations. Agriculture and Human Values, 23, 283-297.

CORSTJENS, M. \& DOYLE, P. (1981) A Model for Optimizing Retail Space Allocations. Management Science, 27, 822-833.

DANNEELS, E. (2002) The dynamics of product innovation and firm competences. Strategic Management Journal, 23, 1095-1121.

DE FERRAN, F. \& GRUNERT, K. G. (2007) French fair trade coffee buyers' purchasing motives: An exploratory study using means-end chains analysis. Food Quality and Preference, 18, 218-229.

DE STANDAARD (2005) Consument niet oorzaak biokrimp.

DONOVAN, R. \& ROSSITER, J. (1982) Store atmosphere: an environmental psychology approach. Journal of Retailing 58, 58, 34-57.

HAMM, U. \& GRONEFELD, F. (2004) The European Market for Organic Food: Revised and Updated Analysis. Organic Marketing Initiatives and Rural Development, 5, 165.

HUGHES, A. (2005) Corporate strategy and the management of ethical trade: the case of the UK food and clothing retailers. Environment and Planning, A 37(7), 1145 - 1163

JONES, P., CLARKE-HILL, C., SHEARS, P. \& HILLIER, D. (2001) Case Study: retailing organic foods. British Food Journal, 103, 358-363. 
JONES, P., COMFORT, D., HILLIER, D. \& EASTWOOD, I. (2005) Corporate social responsibility: a case study of the UK's leading food retailers. British Food Journal, 107, 423-435.

JOOKEN, K. \& NICLAES, G. (2002) Carrefour lonkt naar de top, prijsvergelijking in de supermarkten. Test Aankoop, 454, 25-28.

KOTLER, P. (1974) Atmospherics as a marketing tool. Journal of Retailing 49, 40-64.

KRYSTALLIS, A. \& CHRYSSOHOIDIS, G. (2005) Consumers' willingness to pay for organic food - Factors that affect it and variation per organic product type. British Food Journal, 107, 320-343.

LABARRE, V. \& STARQUIT, G. (2005) Prijzen in de supermarkten. Test Aankoop, 486, 2838.

LAZER, W. K., E. (1961) The retailing mix: Planning and management. Journal of Retailing, 37, 34-41.

LIEBERMAN, M. \& MONTGOMERY, D. (1998) First-Mover (Dis)advantages: Retrospective and Link with the Resource-Based View. Strategic Management Journal, 19, 11111125.

MICKWITZ (1959) Marketing and Competition. Helsingfors; Finland: Centraltrycheriet.

MIDMORE, P., NASPETTI, S., A-M, S., VAIRO, D., WIER, M. \& ZANOLI, R. (2005) Consumer Attitudes to Quality and Safety of Organic and Low Input Foods: a review.

MONDELAERS, K. \& VAN HUYLENBROECK, G. (2005) De markt en de consument van bioproducten. Biologische landbouw: Mens, Markt en Mogelijkheden. Lannoo.

MORSCHETT, D., SWOBODA, B. \& SCHRAMM-KLEIN, H. (2006) Competitive strategies in retailing--an investigation of the applicability of Porter's framework for food retailers. Journal of Retailing and Consumer Services, 13, 275-287.

ORGANIC MONITOR (2006) The EUROPEAN Market for ORGANIC Food \& drink.

ORGANIC MONITOR (2007) The global market for organic food and drink.

OUGHTON, E. \& RITSON, C. (2007) Food consumers and organic agriculture. IN COOPER, J., LEIFERT, C. \& NIGGLI, U. (Eds.) Handbook of organic food quality and safety. Abington, Cambridge, England, Woodhead Publishing Ltd; sales@woodheadpublishing.com.

PADEL, S. \& MIDMORE, P. (2005) The development of the European market for organic products: Insights from a Delphi study. British Food Journal, 107, 626-647.

PORTER, M. (1985) Competitive advantage - Creating and sustaining superior performance. , New York, Free Press.

RICHTER, T. \& HEMPFLING, G. (2002) The supermarket study 2002 - Organic products in European Supermarkets FiBL.

RICHTER, T. \& PADEL, S. (2007) The European Market for Organic Food. The World of Organic Agriculture - statistics \& emerging trends 2007. Switzerland.

SAHOTA, A. (2007) Overview of the Global Market for Organic Food and Drink. IN WILLER, H. \& YUSSEFI, M. (Eds.) The World of Organic Agriculture. Frick, Suisse.

SANCHEZ, R. \& HEENE, A. (Eds.) (2004) The new strategic management: Organization, Competition, and Competence, New York, John Wiley \& Sons, Inc.

SANS, P. (2003) La qualité différenciée de la viande bovine. La nécessaire stratégie d'innovation. Biotechnol. Agron. Soc. Environ., 7, 151-160.

STOCKEMER, C. \& VAN RAEMDONCK, D. (2005) Is bio still hot? . GFK Benelux, GfK Freshflash, 2005, 11.

VLAM (2006) Bio groeit opnieuw dankzij groeiend aantal kopers. Bioverbruik in 2005. Vlaams Centrum voor Agro- en Visserijmarketing, Brussels.

WILLER, H. \& YUSSEFI, M. (2007) The World of Organic Agriculture - Statistics and Emerging Trends 2007 
International Federation of Organic Agriculture Movements (IFOAM), Bonn, Germany.

WIND, Y. (1982) Product Policy: Concepts Methods, and Strategy. Reading, Massachusetts: Addson-Wesley Publishing Company, 107-148.

WIRTHGEN, A. (2005) Consumer, retailer, and producer assessments of product differentiation according to regional origin and process quality. Agribusiness, 21, 191-211.

YIRIDOE, E. K., BONTI-ANKOMAH, S. \& MARTIN, R. C. (2005) Comparison of consumer perceptions and preference toward organic versus conventionally produced foods: A review and update of the literature. Renewable Agriculture and Food Systems, 20, 193205.

ZANOLI, R., BÄHR, M., BOTSCHEN, M., NASPETTI, S., LABERENZ, H. AND THELEN, E (2004) The European consumer and organic food, Aberystwyth, School of Management and Business.

ZANOLI, R. \& NASPETTI, S. (2002) Consumer motivations in the purchase of organic food: a means-end approach. British Food Journal, 104, 643-653. 